\title{
16 HATE SPEECH IN THE UNITED STATES AND SOUTH AFRICA: A LEGAL AND COMPARATIVE ANALYSIS
}

\section{Johan D. van der Vyver ${ }^{1}$}

My academic career is deeply rooted in distant countries that are worlds apart from one another. I am a member of the faculty in the School of Law of Emory University in Atlanta, Georgia, in the United States of America, and an Extraordinary Professor in the Department of Private Law of the University of Pretoria in South Africa. As far as freedom of speech is concerned, the systems that prevail in the United States and in South Africa are also in substance worlds apart. Whereas freedom of speech is a basic norm of the American constitutional system, South African law is by contrast founded on the protection of human dignity and consequently places radical constraints on the publication of defamatory language; and in order to counteract group rivalries amongst traditionally divided population groups, the "new South Africa" includes radical constraints on speech and action that could be offensive to any of the racial, ethnic, religious or linguistic factions within the South African community.

\section{FREEDOM OF SPEECH IN THE UNITED STATES}

Constitutional protection of human rights in the United States is in essence founded on libertarian principles in which the First Amendment freedoms (freedom of religion, freedom of speech, freedom of the press and the right to petition the Government for a redress of grievances) are of special significance. For very special historical reasons, the First Amendment freedoms, notably freedom of speech, constitute die Grundnorm (the basic norm) of the entire system of human rights protection..$^{2}$ If a conflict between different constitutional rights and freedoms were to emerge, the courts must always attempt to "balance" those conflicting rights or freedoms so as to afford equal protection to all of them. However, should freedom of speech be in irreconcilable conflict with any of the other constitutionally protected rights and freedoms, it would prevail. The First Amendment freedoms have thus been proclaimed to be the "preferred freedoms", defined by Chief Justice Earl Warren as "a scale of

1 IT Cohen Professor of International Law and Human Rights, Emory University School of Law; Extraordinary Professor in the Department of Private Law, University of Pretoria.

2 See Van der Vyver JD. 1995. "Constitutional Free Speech and the Law of Defamation", South African Law Journal 112:593-594, 595; Van der Vyver JD. 1998. "Universality and Relativity of Human Rights: American Relativism", Buffalo Human Rights Law Review 4:60. 


\section{Religion, Hate Speech, Diversity and Equality}

constitutional values," ${ }^{3}$ and which means that the presumption of legality of legislation can more readily be rebutted when such legislation restricts First Amendment freedoms than would be the case when economically qualified rights are at stake. ${ }^{4}$

In Palko v. Connecticut, Justice Benjamin Cardozo referred to freedom of thought and speech as "the matrix, the indispensable condition of nearly every other form of freedom." ${ }^{5}$ In Schneider v. State, Justice Owen Roberts accordingly proclaimed:

This court has characterized the freedom of speech and that of the press as fundamental personal rights and liberties. The phrase is not an empty one and was not lightly used. It reflects the belief of the framers of the Constitution that exercise of the rights lies at the foundation of free government by free men. It stresses, as do many opinions of this court, the importance of preventing the restriction of enjoyment of these liberties. ${ }^{6}$

In Saxbe v. Washington Post Co., Justice Lewis Powell, having noted that "the First Amendment protects important values of individual expression and personal self-fulfillment," went on to say:

What is at stake here is the societal function of the First Amendment in preserving free public discussion of governmental affairs. No aspect of that constitutional guarantee is more rightly treasured than the protection of the ability of our people through free and open debate to consider and resolve their own destiny ... It [the First Amendment] embodies our Nation's commitment to popular self-determination and our abiding faith that the surest course for developing sound national policy lies in a free exchange of views on public issues. And public debate must not only be unfettered; it must also be informed. For that reason this Court has repeatedly stated that First Amendment concerns encompass the receipt of information and ideas as well as the right of free expression. ${ }^{7}$

Any limitation of First Amendment freedoms, for whatever reason, would be unconstitutional, except in highly exceptional circumstances. Since the American constitutional system subordinates considerations of human dignity to the salience of First Amendment freedoms, it has, for example, found all kinds of constitutional obstacles in well-intended legislative efforts to curtail child pornography, ${ }^{8}$ and degraded the law of defamation to almost oblivion.

3 United States v. Robel, 389 US 258, at 263 (1967).

$4 \quad$ United States v. Caroline Products Co, 304 US 144 (1938).

5 Palko v. Connecticut, 302 US 319 (1937).

6 Schneider v. State, 308 US 147, at $161(1939)$.

7 Saxbe v. Washington Post Co, 417 US 843, 862-63 (1974).

8 See, for example, Reno v. American Civil Liberties Union, 521 US 844 (1997) (striking down the Communications Decency Act of 1996 on First Amendment grounds); American Civil Liberties Union v. Reno, 217 F 3rd 162 (3rd Cir, 2000) 
For example, in New York Times Co. v. Sullivan, the United States Supreme Court decided that a public official must prove "actual malice" if he or she were to claim damages for libel that relates to his or her official acts; ${ }^{9}$ that is "knowledge that it [the statement] was false or with reckless disregard of whether it was or not."10 The court held that "debate on public issues should be uninhibited robust, and wide-open,"11 and that a malicious motive on the part of the defendant will not be presumed but must be proved by the plaintiff. ${ }^{12}$ Needless to say, in countries where human dignity and equality trumps considerations of free speech, the proscription of child pornography and hate speech do not present any constitutional obstacles.

American jurisprudence dealing with hate speech is particularly instructive. It should be borne in mind that "speech" is given a broad meaning in the United States. The concept of constitutionally protected speech has been extended to include saluting or not saluting the national flag by learners at the beginning of the school day, ${ }^{13}$ the burning of a cross or Nazi swastika that would arouse anger, alarm or resentment, ${ }^{14}$ flag burning or desecrating the flag of the United States as a means of political protest, ${ }^{15}$ or wearing a black armband to protest against the Vietnam War. ${ }^{16}$

In 1992, the U.S. Supreme Court was called upon to judge the constitutionality of a municipal ordinance which rendered it a misdemeanor for someone to place "on public or private property a symbol, object, appellation, characterisation or graffiti, including, but not limited to, a burning cross or Nazi swastika" if the person concerned had reason to know that the display would anger or alarm

(upholding an injunction relating to the Child Online Protection Act, holding that the legislation will "more likely than not" be found to be unconstitutional as constituting an undue restriction of First Amendment freedoms); United States $v$. Playboy Entertainment Group, Inc, 529 US 803 (2000) (declaring unconstitutional a provision in the Telecommunications Act of 1996 regulating signal "scrambling" to ensure that only paying viewers will have access to Playboy programmes, holding that the provision, being a "content-based regulation of a form of speech that enjoyed First Amendment protection", violated the constitutional free speech guarantees); Ashcraft v. Free Speech Coalition, 535 US 234 (2002) (the Court invalidating sections of the Child Pornography Act of 1996 as being "over broad" because they purported to ban sexually explicit images that appears to depict or conveys the impression of depicting minors).

9 New York Times Co v. Sullivan, 376 US 254, at 279-80 (1964).

10 New York Times Co v. Sullivan, 280.

11 New York Times Co v. Sullivan, 270, See also Pennekamp v. Florida, 328 US 311, at 347 (1946) (holding that freedom of discussion should be given "the widest range compatible with the essential requirement of the fair and orderly administration of justice" $)$.

12 New York Times Co v. Sullivan, 283-84.

13 West Virginia State Board of Education v. Barnette, 319 US 624 (1943).

14 RAV v. City of St. Paul, Minnesota 505 US 377 (1992).

15 Street v. New York, 394 US 576 (1969); Smith v. Coguen, 415 US 566 (1974); Texas v. Johnson, 491 US 397, at 400 (1989); United States v. Eichman, 486 US 310 (1990).

16 Tinker v. Des Moins Independent Community School District, 393 US 503 (1969). 


\section{Religion, Hate Speech, Diversity and Equality}

others, based on "race, color, creed, religion or gender". ${ }^{17}$ The ordinance, the Court found, violated the free speech provision of the First Amendment, because it prohibited "otherwise permitted speech solely on basis of the subject the speech addresses". According to the concurring justices, the unconstitutionality of the ordinance derived from the fact that it only prohibited hate speech delivered by symbols and because the speech that fell outside the scope of the ordinance can only hurt feelings or cause resentment.

Hate speech legislation in America is mostly confined to sanctioning higher sentences than normally prescribed if the crime was motivated by hostile feelings toward a group to which the victim belongs. The U.S. Supreme Court accordingly upheld the constitutionality of a law of Wisconsin that made provision for increased sentences in cases where the crime was prompted by hate. ${ }^{18}$ The Court reasoned that the law was directed against conduct and not expression, and that the motivation that prompted a criminal act is a legitimate consideration when determining an appropriate sentence. In another matter, the U.S. Supreme Court struck down a law of New Jersey which authorised a judge to increase a sentence above the maximum prescribed by law in cases where the crime was racially motivated. ${ }^{19}$ The Court decided that it was for a jury and not the judge to determine facts - in this instance a racial bias - that would expose an accused to a penalty which exceeds the prescribed maximum.

In a case concerning an anti Ku Klux Klan measure of the state of Virginia, the U.S. Supreme Court again upheld the constitutionality of a state law which created a felony consisting of the burning of a cross "on the property of another, a highway or a public place ... with the intent of intimidating any person or group." 20 The Court noted that had the cross been burnt at a political rally, the act would have constituted political speech and would therefore have been protected under the First Amendment free speech provision.

More recently, in the case of Snyder v. Phelps, the United States Supreme Court was called upon to consider the legality of the display of offensive placards denouncing, among other things, homosexuality in the military, by members of the Westboro Baptist Church in the proximity of the funeral of an American marine killed in Iraq in the line of duty. ${ }^{21}$ The judgment, delivered by Chief Justice John Roberts, proclaimed that speech on a public sidewalk, relating to a public issue, cannot be legally condemned as a tort of emotional distress, even if the speech is "outrageous".

17 RAV v. City of St. Paul, Minnesota, supra $\mathrm{n} 13$.

18 State v. Mitchell, 508 US 476 (1993).

19 Apprendiv. New Jersey, 530 US 466 (2000).

20 Virginia v. Black, 538 US 343 (2003).

21 Snyder v. Phelps, 562 US 443 (2011). 


\section{HATE SPEECH IN SOUTH AFRICAN LAW}

Comparing the American constitutional system with the one of South Africa is particularly instructive in the context of our theme: the one placing a particularly high premium of free speech, and the other subjecting freedom of expression to constraints dictated by the supreme concern for human dignity. It is important to emphasise that American judgments relating to freedom of speech do not constitute "comparable foreign case law" that should be taken into accounts by courts of law when interpreting the Bill of Rights. ${ }^{22}$ Statements such as those of Judge Rex van Schalkwyk in Mandela $v$. Falati, proclaiming with reference to American cases, "the primacy of the freedom of speech" and depicting freedom of expression as "the freedom upon which all others depend," 23 are therefore simply incorrect. Nor can one concede the proposition that "the Constitution creates no hierarchy of fundamental rights." ${ }^{24}$

It is important to emphasise that a strictly libertarian constitutional system, like the one of the United States, is not suited to the needs of a plural society, like the one of South Africa, where polarised group rivalries take on epidemic proportions. A nation in the making must value the demands of reconciliation to be a supreme priority and cannot afford to permit expressions of intolerance, or group-related biases and stereotyping, which counteract that noble cause. It must seek to accomplish a fair balance between freedom to express one's beliefs and the proscription of speech that is offensive and would for that reason prolong the ongoing process of reconciliation.

The South African nation comprises perhaps the most diverse plural composition in the entire world; furthermore, it is known for the polarisation of factions of the population. ${ }^{25}$ Group rivalries are still rife in South Africa as a feature of the country's demographic divides. Dealing with such rivalries and orchestrating reconciliation are central to social engineering within that troubled land. Constitutional change in South Africa that took effect on

22 See Constitution of the Republic of South Africa, 1996, s 35(1).

23 Mandela v. Falati, 1995 (1) SA 251, at 259; 1994 (4) BCLR 1, at 8 (W). See also De Klerk $\mathcal{E}$ Another v. Du Plessis $\mathcal{E}$ Others, 1995 (2) SA 40, at 51; 1994 (6) BCLR 124, at 134 (T) (Van Dykhorst J referring to a similar submission that "our law of defamation can ... be reviewed in the light of the approach of the United States Supreme Court", but preferring not to express an opinion as to the legitimacy of this "interesting vista" and its implications); Gardener v. Whitaker, 1995 (2) SA 672, at 688; 1994 (5) BCLR 19, at 34 (E) (Froneman J including references to American jurisprudence in his comparative outline to substantiate the importance of freedom of speech, without emphasising the necessity of placing the judgments concerned in a proper comparative perspective).

24 Gardener v. Whitaker, supra n 21, at SA 690; at BCLR 36.

25 See S v. Makwanyane and Another, 1995 (3) SA 391, 19956 BCLR 665, para 308 (CC) (Justice Mokgoro referring to South Africans having "a history of deep division characterised by strife and conflict"); and Du Toit v. Minister for Safety and Security $\mathcal{E}$ Another, 2009 (6) SA 128, para 17 (CC) (Chief Justice Langa stating that "the South African nation was for decades a deeply divided society characterised by gross violations of fundamental human rights"). 
27 April 1994 was designed to innovate social, political and legal structures that would be radically different from those of the country's past history. The new constitutional dispensation in that sense emanated from a reactionary response to the evils of the preceding era. ${ }^{26}$ The Constitution of the Republic of South Africa, 1996, while thus recognising "the injustices of our past", ${ }^{27}$ accordingly depicted the new South Africa as "an open and democratic society based on human dignity, equality and freedom." ${ }^{28}$ The constitutional Bill of Rights provided the legally enforceable backing for such a society: Any institution associated with discrimination and repression of apartheid South Africa must be taken to be incompatible with the values embodied in the kind of society the country now aspired to be. ${ }^{29}$

The drafters of the South African constitution accordingly rejected the segregation of rival ethnic, religious and linguistic communities as well as the promotion of cultural, religious or linguistic homogeneity within the nation, as a means of counteracting group-related tensions in the country's social construct. Instead, they opted for creating - in the celebrated words of Archbishop Desmond Tutu - "a rainbow nation". The new constitutional dispensation seeks to promote pride in one's particular ethnic, religious or linguistic identities. However, the South African dispensation is also sensitive to the notion that pride in one's group identity does not elevate one to a superior status in the community. The respect of others for one's cultural values, religious persuasions or linguistic preferences demands full respect for the culture, religion and language of others. The constitutional principle that applies in this regard has been reduced to perhaps the most basic moral directive for a "new South Africa"; one that finds expression in the concept of ubuntu (in Zulu) or botho (in Tswana) "an idea based on deep respect for the [inner] humanity of another". ${ }^{30}$ Ubuntu translates into "humaneness" and constitutes "part of our rainbow heritage". ${ }^{31}$ It stands in sharp contrast to "dehumanising and degrading the individual". ${ }^{32}$ Justice Albie Sachs on occasion referred to ubunthu-botho in the sense of "civility" as "a precondition for the good functioning of contemporary democratic societies". He noted that "civility in a constitutional sense involves more than just courtesy

26 See Van der Vyver JD. 1991. "Constitutional Options for Post-Apartheid South Africa", Emory Law Journal 40:785-787,789; Du Plessis \& Others v. De Klerk E Another, 19963 SA 850 (CC); 19965 BCLR 658 (CC), para 90 (per Ackermann, J).

27 Constitution of the Republic of South Africa, 1996, Preamble.

28 Id., s 36(1), 39(1)(a). See also s 7(1).

29 See Brink v. Kitshoff NO, 19964 SA 197 (CC); 19966 BCLR 752 (CC), para 33 (per O’Regan, J). See also S v. Makwanyane E Another, supra n 23, para 218 (per Langa, J), para 262 (per Mahomed, J), para 322 (per O’Regan, J); Shabalala E Others v. Attorney-General of the Transvaal \& Another, 19961 SA 725 (CC); 199512 BCLR 1593 (CC), para 26 (per Mahomed, J); Ferreira v. Levin NO \& Others; Vryenhoek $\mathcal{E}$ Others v. Powell NO E Others, 19961 SA 984 (CC), 19961 BCLR 1 (CC), para 29.

30 Dikoko v. Mokhatla, 2006 (6) SA 235; 20071 BCLR 1, para 68 (CC). See also id., para 69.

31 S v. Makwanyane E Another, supra n 23, para 308 (per Mokgoro, J).

32 Id., para 250 (per Langa, J). 
and good manners ... It presupposes tolerance for those with whom one disagrees and respect for the dignity of those with whom one is in dispute." 33

South African law therefore does not uphold the almost incontestable sanctity of freedom of speech that the American constitutional system does. In South African law, "certain expressions do not deserve constitutional protection because they have the potential to impinge adversely on the dignity of others and cause harm." 34 In South Africa, "the right to freedom of expression is not a pre-eminent freedom ranking above all others." ${ }^{35}$ In this respect, it "differs fundamentally from the balance struck in the United States", where freedom of speech constitutes the basic norm of the entire rights regime. ${ }^{36}$

The South African Constitution accordingly subjects the freedom of expression to limitations, which include a prohibition of the "advocacy of hatred that is based on race, ethnicity, gender or religion, and that constitutes incitement to cause harm."37 Under the Promotion of Equality and Prevention of Unfair Discrimination Act, "no person may publish, propagate, advocate or communicate words ... against any person, that could reasonably be construed to demonstrate a clear intention to (a) be hurtful; (b) be harmful or to incite harm; (c) promote or propagate hatred." 38 The Act, by prohibiting unfair discrimination, ${ }^{39}$ hate speech, ${ }^{40}$ harassment," and "dissemination and publication of information that unfairly discriminates," 42 is clearly based on a link between the protection of human dignity and the right to equality. It defines hate speech as words "that could reasonably be construed to demonstrate a clear intention to (a) be hurtful; (b) be harmful or to incite harm; (c) promote or propagate hatred"; 43 however, "bona fide engagement in artistic creativity, academic and scientific inquiry, fair and accurate reporting in the public interest" do not constitute hate speech. ${ }^{44}$

33 Masetlha v. President of the RSA and Another, 2008 (1) SA 566; 20081 BCLR 1, para 238 (CC).

34 Du Toit v. Minister for Safety and Security $\mathcal{E}$ Another, supra n 23, para 32 (CC).

35 S v. Mamabolo (E TV E Seven Others Intervening), 2001 (3) SA 409, 20015 449, para 41 (CC).

36 Id., para 40; Van der Vyver JD. 1997. “Constitutional Protection of Children and Young Persons", in Robinson JA (ed). The Law of Children and Young Persons in South Africa. Durban: Butterworths, 282; and Van der Vyver JD. 2005. "Limitations of Freedom of Religion or Belief: International Law Perspectives", Emory International Law Review 19:508.

37 South African Constitution, 1996, s 16(2)(c).

38 The Promotion of Equality and Prevention of Unfair Discrimination Act 4 of 2000, s 10(1). See Krüger R. 2011. "Small Steps to Equal Dignity: The Work of the South African Equality Courts", The Equal Rights Review 7:27.

39 The Promotion of Equality and Prevention of Unfair Discrimination Act, s 6, 7, 8 and 9.

40 The Promotion of Equality and Prevention of Unfair Discrimination Act, s 10(1) (c).

41 The Promotion of Equality and Prevention of Unfair Discrimination Act, s 11.

42 The Promotion of Equality and Prevention of Unfair Discrimination Act, s 12.

43 The Promotion of Equality and Prevention of Unfair Discrimination Act, s 10(1).

44 The Promotion of Equality and Prevention of Unfair Discrimination Act, s 12. 


\section{Religion, Hate Speech, Diversity and Equality}

The "new South Africa" is thus founded on zero tolerance for words and conduct offensive to others. It has therefore been decided that depicting members of particular population groups as "hotnot", "kaffir", "rooinek", "boer" or "coolie" is strictly forbidden since such names "have for decades been used to bring people of different races into contempt." ${ }^{45}$ Other cases that have attracted special attention in recent times include one in which the conservative Christian owners of a grocery store open to the public refused to serve a Muslim client wearing a fez were reprimanded because their conduct amounted to unbecoming discrimination based on religion. ${ }^{46}$ It was also decided that the media were under legal constraint not to publish cartoons that appeared in a Danish newspaper depicting the Prophet Mohammed as a terrorist, because those comic strips "advocate hatred and stereotyping of Muslims." 47 A newspaper report that likened homosexuality to bestiality could not be tolerated under the assumption of freedom of the press because it promoted hatred against the gay and lesbian communities. ${ }^{48}$

A prominent politician, Julius Malema, has been called on the carpet on several occasions for hate speech transgressions. While he was leader of the African National Congress Youth League (2008-2012), he was reprimanded for the chanting of a "freedom song" that includes the phrase dibulu iBhunu (shoot the Boer), because it was found to be offensive to the Afrikaans-speaking section of the South African nation and as such violates the proscription of offensive language. ${ }^{49}$ The matter was taken on appeal by Malema and the African National Conference, but was settled on the basis of the appellants agreeing "that certain words in certain freedom songs may be experienced as hurtful by members of minority communities" and "to act with restraint to avoid the experience of such hurt". The settlement was made an order of court.

Malema was also brought to trial in the Equality Court in 2010 by the SONKE Gender Justice organisation for stating in an address of 22 January 2009 to

45 Decision of the Broadcasting Complaints Commission in P Johnson v. 94.7 Highveld Stereo, Case No 07/2002, 14 February 2002.

46 Woodways CC v. Moosa Vallie, Case No A251/05 (HC Western Cape, 31 August 2009).

47 Jamait-Ul-Ulama of Transvaal v. Johncom Media Investment Ltd and Others, Case No 1127/06 (W), 3 February 2006. The ban was subsequently lifted because the comic strips were widely published on the Internet.

48 In South African Human Rights Commission v. Jon Qwulane, Case No 44/EQ JHB (31 May 2011), the Equality Court at the Johannesburg Magistrate's Court demanded an unqualified public apology to the gay and lesbian community from - and imposed a fine of R100,000 to be paid by - Jon Qwulane (subsequently the South African ambassador in Uganda) for a newspaper article he wrote under the heading "Call Me Names, but Gay Is NOT OK", in which he compared homosexuality with bestiality.

49 Agriforum and Another v. Malema and Another, 2011 (6) SA 240; 2011 BCLR 1289 (EqC). The matter was referred to the Equality Court as a matter of great urgency by the North Gauteng High Court in Pretoria. Agriforum and Another v. Malema, 2010 (5) SA 235 (GNP). "Boer" means "farmer" but is also commonly used to denote the white Afrikaans-speaking citizens of South Africa. 
students of the Cape Peninsula University of Technology that the women who accused ANC President Jacob Zuma of rape actually had a "nice time" with him, and he went on to say: "When a woman didn't enjoy it, she leaves early in the morning. Those who had a nice time will wait until the sun comes out, request breakfast and ask for taxi money." The Equality Court found that the utterance complained of amounted to hate speech and harassment, that Malema must issue a public apology, and that he must pay People Opposed to Women Abuse (POWA) an amount of R50,000 within one month of date of the judgment. ${ }^{50}$

Malema was eventually (for other reasons) expelled from the ANC and subsequently founded a new political party, the Economic Freedom Fighters (EFF), of which he is currently the leader. The EFF is the third most political party in South Africa, having gathered $6.35 \%$ of the votes in the 2014 general elections, thereby gaining 25 seats in Parliament. The important point in the context of this essay is that Malema has clearly not seen the last of the Equality Court. Statements such as the following are commonplace in his public addresses: The Afrikaans language must fall; it must not be spoken; we must not be compelled to speak that language; we do not compel you to speak Shangaan or Zulu.

Malema is not the only prominent politician to have been confronted with hate speech complaints. In January 2016, a complaint was lodged with the South African Human Rights Commission against President Jacob Zuma for a statement he made on land reform in Rustenburg on occasion of the ANC's 104th anniversary dinner, saying: "The source of poverty, unemployment, and inequality is land. It was taken ... not bought. Stolen. But the government of the people has to buy it back as if it was sold." 51 The complaint was filed by Pieter Groenewald, the Freedom Front Plus parliamentary spokesman on land affairs, who maintained that the reference to "stolen land" in South Africa refers to white people and fuels the racial hatred between whites and blacks in the country. Zuma was required to respond to the complaint by 4 July 2016, which he failed to do.

Earlier, in February 2015, a complaint was lodged by the Freedom Front Plus party with the South African Human Rights Commission against Jacob Zuma for a statement he made at a fundraising dinner, depicting the arrival of Jan van Riebeeck, who in 1652 founded a white settlement on behalf of the Dutch East India Company at what subsequently became Cape Town, as the cause of all the problems in South Africa: "You must remember that a man called Jan van Riebeeck arrived here on 6 April 1652, and that was the start of the trouble in this country. What followed were numerous struggles and wars and deaths and

50 Sonke Gender Justice Network v. Malema, Case No 02/2009, 2010 (7) BCLR 729; [2010] ZAEQC 2 (15 March 2010).

51 See Zuma Complaint Lodged with SAHRC. Online at: http://www.iol.co.za/news/ politics/zuma-complaint-lodged-wit-sahrc-1972819 
the seizure of land and the deprivation of the indigenous peoples' political and economic power." 52

Another case that attracted considerable public interest was one involving an elderly lady, Penny Sparrow, a retired real estate agent, who was appalled by the extensive littering of Scottburgh Beach on the Natal coast which she visited on New Year's Day, and on 3 January 2016 posted on Facebook the statement: "Dear, o, dear, from now on I shall address the blacks of South Africa as monkeys as I see the cute little wild monkeys as the same, pick, drop and litter." The defendant did not attend the proceedings because she allegedly feared for her life. The Equality Court decided that the words amounted to hate speech and ordered her to pay damages in the sum of R150,000 to the Oliver and Adelaide Tambo Foundation, plus the costs of the proceedings. ${ }^{53}$

Currently, a case against Judge Mabel Jansen is pending. She was extremely upset by the large number of rape cases that came before her, in many cases involving victims of tender age. She communicated with a certain Gillian Schutte in a private Facebook exchange in an attempt to find a solution to the problem, stating: "Gillian do you believe that I am even propositioned by my black colleagues who tell me they will be in hotel $x$ and expect me to report there at a specific time? I am shell-shocked. In a culture a woman is there to pleasure them. Period. It is seen as an absolute right and a woman's consent is not required. You may find this hard to accept and unpalatable as I did. I still have to find a black girl who was not raped at about 12. I am dead serious." Ms Schutte made the statement public to expose the "deep racism and colonial thinking" prevalent in South Africa. ${ }^{54}$ What was perceived as racist stereotyping resulted in Judge Jansen being placed on indefinite leave while further action against her is being contemplated. The matter has been referred by the Democratic Alliance to the Judicial Service Commission with a view to her being defrocked.

It must be emphasised that Judge Jansen does not appear to be a racist. In 1977 she adopted two black African children, who testified what a good mother she was to them. Her concern about the frequency of rape in the country is also not without foundation. It is estimated that 500,000 rape cases take place in the country every year. Women's groups estimate that a woman is raped in South Africa on average every 26 seconds. The South African Police Service disagrees; it estimates that a woman is raped on average every 36 seconds. Statistics provided by the South African Police Service show that in 2014/15 the reported rape cases amounted to 43,195. Reported child rape cases in 2011/12 amounted to 21,128 ; in 2012/13 to 20,702; and in 2013/14 to 18,528 . It is estimated that $40 \%$ of South African woman will be raped during their lifetime. These statistics are

52 See 2015. “Jacob Zuma under Investigation for Using Hate Speech”, The Guardian, 19 February.

53 ANC v. Penny Sparrow, Case No 01/16, [2016] ZAEQC 1 (10 June 2016).

54 See 2016. "South African Judge Mabel Jansen in Race Rape Row", BBC, 9 May. 
confined to reported rape cases, and it is estimated that only one in nine rape cases are reported.

Attributing the high rate of rape cases in South Africa to African culture nevertheless constitutes a violation of the hate speech constraints incorporated into South Africa law. However, the objective of those constraints - counteracting group rivalries in the country - presupposes that the offensive statement is brought to the knowledge of population groups that will be offended by the allegation concerned. It would therefore appear that the primary offender was not Judge Jansen, who conveyed the offensive allegation to a fellow white South African in a private communication, but the person who splashed it on the Internet for everyone to see.

\section{CONCLUSION}

I have often said that the constitution of a country is its most unexportable commodity. The special significance of freedom of speech in the United States is commendable within the social construct of that country; it is ill suited for a country like the new South Africa which has committed itself to the eventual elimination of group related animosities of the past.

Emphasis on human dignity, rather than individual freedoms, as the most basic premise of human rights protection is clearly in conformity with internationallaw standards. The Universal Declaration of Human Rights and the Covenant on Civil and Political Rights both proclaim that "recognition of the inherent dignity and of the equal and inalienable rights of all members of the human family is the foundation of freedom, justice and peace in the world. ${ }^{5}$ According to its Preamble, the 1981 Declaration on the Elimination of All Forms of Intolerance and of Discrimination Based on Religion or Belief is founded on the basic principles of the Charter of the United Nations that proclaims "the dignity and equality inherent in all human beings". ${ }^{56}$

As far as the elimination of group rivalries is concerned, South Africa has not yet complied with international demands. Despite serious efforts - with constitutional backing - to eliminate group related hostilities in the country, South Africa has not even come close to accomplishing this noble objective. As noted by Chief Justice Pius Langa in 2009: "The process of reconciliation is an ongoing one which requires give and take from all sides." 57 "Our democracy is still fragile," said Judge Eberhard Bertelsmann, adding that "participants in

55 Universal Declaration of Human Rights, Dec. 10, 1948, G.A. Res. 217A, Preamble, first paragraph [emphasis added]; International Covenant on Civil and Political Rights, Dec. 16, 1966, 999 U.N.T.S. 173, Preamble, first paragraph [emphasis added].

56 Declaration on the Elimination of All Forms of Intolerance and Discrimination Based on Religion or Belief, Nov. 25, 1981, G.A. Res. 36/55, U.N. GAOR, 36th Sess., Supp. No. 51, at 171, U.N. Doc. A/RES/36/51.

57 Du Toit v. Minister of Safety and Security, 2009 (6) SA 128, para 28 (CC). See also Agriforum and Another v. Malema and Another E Another, supra n 47, para 11. 


\section{Religion, Hate Speech, Diversity and Equality}

the political and socio-political discourse must remain sensitive to the feelings and perceptions of other South Africans when words were used that were common during the struggle days, but may be experienced as harmful by fellow inhabitants of South Africa today." 58

Following the commendable rule of Nelson Mandela that was focused on reconciliation, a reactionary response to the newly established democracy was quite predictable. Gaining political control of the country initially prompted tremendous euphoria in the mindset of the formerly repressed population. However, it soon emerged that although a large number of Africans benefitted quite considerably from the government policy of remedial action, a vast majority of the population soon realised that many of the poor, uneducated and unemployed are still poor, uneducated and unemployed. Poverty, educational degradation and unemployment are exacerbated by the tremendous population increase in less sophisticated communities. The persistent inequalities between the rich and the poor sparked unrest and violent protests in the country, as well as the escalation of tribalism and racism under the rubric of a twisted perception of self-righteousness. The bottom line of it all is that de facto inequalities constitute primary obstacles in creating a rainbow nation, and as far as the commendable objectives of the Constitutional Assembly are concerned, South Africa still has many more miles to run.

58 Agriforum and Another v. Malema E Another, supra $\mathrm{n} 47$. 